\title{
Groundwater Over-Pumping and Recent Earthquakes in the Northern United Arab Emirates: A Natural Hazard Accentuated by Human Activity
}

\author{
Asma Al-Farraj \\ Geography Department, UAE University, Al-Ain, United Arab Emirates \\ Email: asma@uaeu.ac.ae
}

Received January 3, 2012; revised February 13, 2012; accepted February 25, 2012

\begin{abstract}
At the present day the United Arab Emirates (UAE) is on the flank of the Arabian plate, but some way away from the major modern earthquake epicentres. It normally experiences only minor earthquakes whose epicentres lie along the suture between the Arabian and Asiatic plates in Iran, the Arabian Gulf and the Gulf of Oman. In March 2002 a series of earthquakes occurred in several areas in the northern UAE, with foci along fault lines within the UAE. What made these earthquakes different from earlier earthquakes was their strength and frequency. For the first time in the area, earthquakes of a magnitude 5.5 (on the Richter scale) occurred, and continued over a period of three days. The causes appear to involve more than fault zone and plate tectonics, and may be related to human activity. Tracing the earthquakes during the past three decades indicates that the earthquakes followed major groundwater over-pumping, itself a result of population growth, growth in the number of farms and number of bottled water factories.
\end{abstract}

Keywords: Groundwater Over-Pumping; Earthquakes; Northern UAE; Human Impact

\section{Introduction}

This Before the middle of the 20th century earthquakes were seen as an "act of God". However, today at the beginning of the 21st century it is seems to be possible that some earthquakes could be as the result of an "act of man".

The causes of earthquakes have been summarized in the literature into three reasons, one related two physical theory of fault zones and plate tectonics, and to related to human activities which disturb the natural setting and the nature of the rocks e.g. [1-3]. The first type is a tectonic earthquake, which occurs when rocks break suddenly in response to different geological forces, including plate movements, faults and volcanic activities. There are two types of human-induced earthquakes; collapse-induced and explosion-induced earthquakes. Collapse-induced earthquakes occur in regions of underground mining and caverns. The instantaneous cause of ground shaking is either the collapse of the roof of the mine, or a landslide-produce seismic wave. Such collapses have occurred in Canada and Peru [1]. In addition, to pressure release which may induce collapse, there are also effects on ground water due to a sudden reduction in the confining pressure (p. 160, [1]). Explosion-induced earthquakes are produced by the detonation of chemical or nuclear devices.

Furthermore, water in bedrock has been considered to have an influence on earthquakes. There are some earthquakes which occur either as a result of water accumulation behind dams as in Lake Nasser (on the Nile River), or as a result of water injected into the ground as in Denver Colorado [1]. Since these incidents back in the 1960s there have been many investigations of the influence of water/fluids. During the last three decades there have been intensive studies on the effects of groundwater on earthquakes. For instance, [4] have studied the pore fluid flow effect on the strength of the rock. [5] have reported two mechanisms to stabilize earthquakes by pore fluids. These mechanisms are based on dilatancy strengthening and on an increase of elastic stiffness for undrained as opposed to drained conditions. [6] has illustrated the relationships between groundwater levels and earthquakes prediction in China. [7] put forward a model for episodic flow of high pressure water in fault zones. [8] studied earthquakes that related to hydrologic phenomena. [9] suggested that the strain induced by large crustal earthquakes produces changes in pore fluid apertures that dissipate with time and result in surface deformation. Rock in undrained and drained conditions behaves differently. [10] has put forward suggestions and evidence of positive fluid action on earthquakes, where the fluid 
acts as a shock absorber [11].

The northern United Arab Emirates (UAE) usually experiences only minor earthquakes. It is too far away from any important focus. Earthquake magnitudes in the northern UAE rarely exceed 4.4 on the Richter scale; normally the intensity values are up to III. This means there is normally no serious damage to structures from earthquakes of this magnitude. However, in March 2002 a series of earthquakes of magnitude of 5.5 on the Richter scale made the scientists in the UAE start to consider the phenomena intensively.

For example, the Universities of Sharja and UAE initiated earthquake monitoring stations in Sharja and on the East Coast to record seismic shaking in these areas. The Weather Forecast Centre put forward a project of earthquake monitoring stations to cover the whole of the UAE.

This study aims to examine the possible causes which made these earthquake events stronger than usual. It will consider the possible impact of human activity, as an agent in accentuating earthquakes in the study area.

\section{Physical Setting}

The northern UAE Mountains are part of the Oman Mountains (Figure 1), which extend from Musandam to the southwest part of the Sultanate of Oman. This mountain range is the only tectonically active area in the UAE. It is still undergoing uplift as a result of Arabia-Asia interaction. Thus, it is subjected to minor earthquakes whose epicentres lie along the suture between the Arabian and Asiatic plates in Iran, in the Arabian Gulf and in the Gulf of Oman (Figure 2).

This mountain area is formed primarily of four types of rocks of Mesozoic age, formed on the margins of the Tethys Ocean. The four groups of rocks include; the Musandam carbonates, the Hawasina Schists, the Sumeini group and the Semail ophiolites [12-15]. These four groups of rocks formed over the same period of time but in different environments. The Musandam carbonates were deposited in shallow water on the continental margin. The Hawasina schists were deposited as muds on the ocean basin floor prior to their metamorphism. The Sumeini group were deposited on the continental edge and at the foot of the continental slope. The Semail ophiolites are part of the oceanic crust. During the Late Cretaceous external parts of the continental shelf and adjacent Tethyan deep-sea floor were overthrust onto the continental margin [16-21]. They are now exposed as a series of thrust sheets. These four rock groups form distinctive units within the Musandam Mountains, separated by major fault zones (Figure 1).

Today the UAE is on the flank of the Arabian plate, some distance away from the major modern earthquake

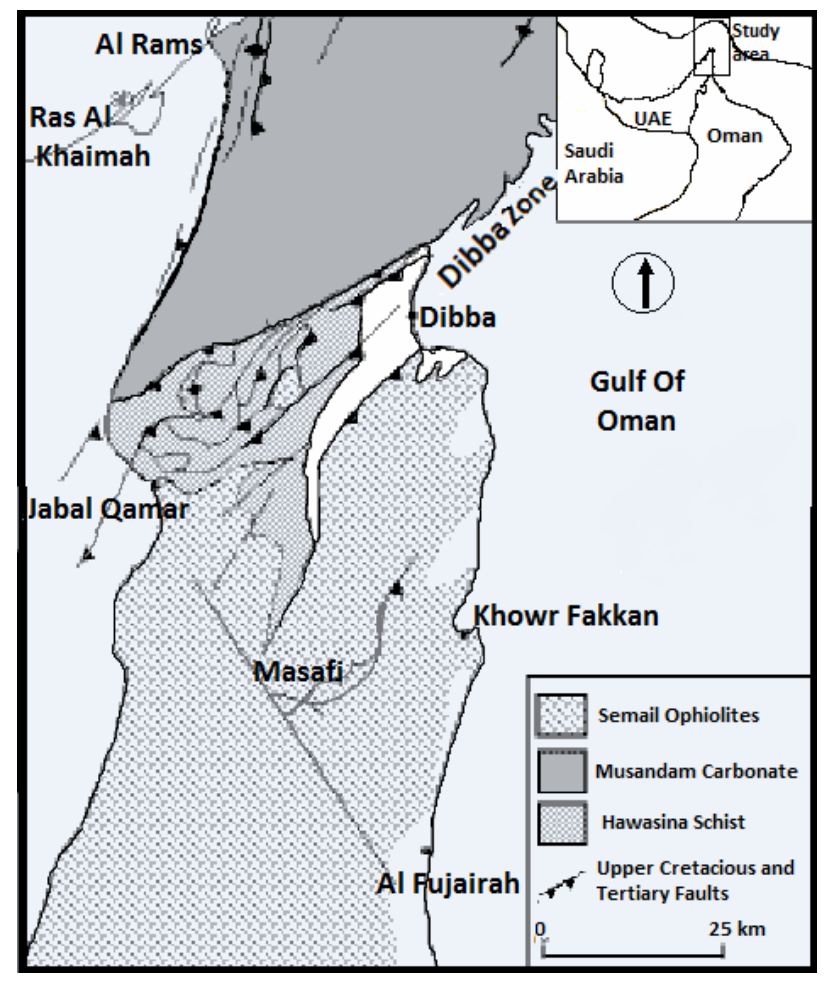

Figure 1. Location of the study area and major fault lines separating the rock units.

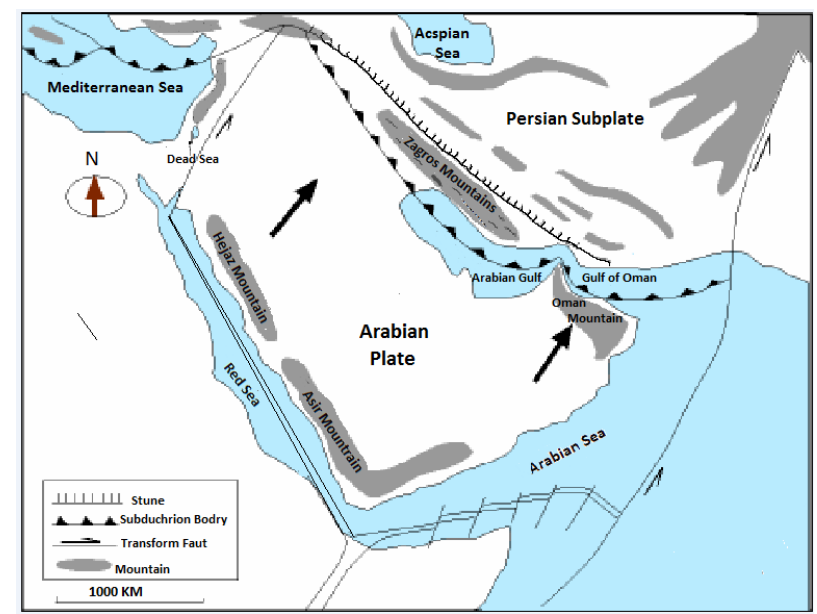

Figure 2. Suture between Arabia and Iran.

epicentres. It normally experiences only minor earthquakes whose epicentres lie along the suture between the Arabia and Asiatic plates.

\section{March 2002 Earthquakes}

Between the 10th and 12th of March 2002 a series of seismic shocks occurred in different areas of the northern UAE. According to the record of earthquakes centres in Oman and Iran, 11 earthquakes and seismic shocks occurred between 10th and 11th of March in the Arabian 
Gulf and Gulf of Oman; 4 in the Oman Gulf, 3 in the Straits of Hurmuz and 4 in the north and centre of the Arabian Gulf. These earthquakes were concentrated in the middle and north of the Gulf of Oman. They passed through the Strait of Hurmuz to the middle and north of the Arabian Gulf, for a distance of $1000 \mathrm{~km}$ perpendicular to the movement of the Arabian plate [22]. This resulted in a series of earthquakes which occurred in several areas in the northern UAE, with a maximum magnitude of 5.5 on Richter scale. The foci of these earthquakes were along the fault lines within the UAE.

On 10th March the first earthquakes occurred at $\mathrm{Al}$ Nahwah south of Khor Fakan. It happened for a few seconds only. No damage occurred but it was felt by people. Late at night another earthquake occurred at Massafi, for a few seconds. This repetition of earthquakes forced some people to leave their homes. The fears among the people resulted in tens of telephone calls made to the Newspapers and to the Meteorology Centre in the UAE.

On 11th March another series of earthquakes occurred with strength of 5.1 on the Richter scale. These earthquakes resulted in damage to 2 schools, 2 police stations and to the fire department at Massafi. In addition, rocks fell on the road between Dibba and Massafi. All damages were to the walls and ceilings of old buildings. About 180 houses were damaged by the incident. The main damage was the fear among the people in the affected areas, which led them to spend a week in tents.

In the early morning of 12th March another series of strong earthquakes occurred in the area. Four of them were in Massafi; they were the strongest (5.5 in Richter scale) and caused damage to some buildings (Schools, Mosques), and rock falls on the roads. The rest were weaker and only felt by the people.

\section{Human Activity as a Potential Intensifier of the Earthquakes the Template}

Low magnitude earthquakes occur in the UAE related directly to the Arabian plate moving towards Asia and to fault zones in the effected areas. However, these sudden higher magnitude earthquakes cannot be related to this broad picture. It may be that changes have occurred in the magnitude and weight of the rock and groundwater in the area. Because changes in the physical characteristics of the study area are unlikely, it is highly likely that such changes are the result of human activities, involving groundwater over-pumping and/or mining.

There are two main possible reasons which could be suggested as causes of earthquake accentuation:

1) groundwater over-pumping;

2) rock mines and explosions affected the rock cracks, and one possible reason for the severity of the effect: building age and materials.

\subsection{Groundwater Over-Pumping}

The groundwater sources in the UAE date back to late Quaternary wetter/pluvial periods. At present the UAE is part of the arid zone, with an annual rainfall of $<200 \mathrm{~mm}$. This amount of rain is mainly lost by evaporation (72\%) and $14 \%$ reaches the sea. Another $14 \%$ only, infiltrates and feeds the groundwater table. This only accounts for the $30 \%$ of the groundwater consumed in the area [23]. The rest is effectively depleting late Quaternary water.

Before the 1970s the water drawn from the groundwater was approximately equal to groundwater recharge. However, from the early 1970s with huge immigration into the area, together with industrial development and agricultural expansion, the consumption of groundwater greatly increased. In addition there is the activity of water companies which produce water not only for local needs, but for export overseas. There are 30 bottled mineral water companies in the UAE. At least 33\% of them export water to countries which are not within the arid zone, such as Japan and France and other 20 countries in Asia, Africa and Europe [24]. During the war in Afghanistan in year 2001/2002 some of these bottled mineral water companies were exporting water to the US army in Afghanistan. In the summer of 2002, the problem of groundwater wells drying up was exposed, when the farmers in the northern UAE complained about the lack of groundwater on their farms. Exploitation of groundwater gives huge profits for water companies, but causes huge damage to the environment [24].

The over-pumping of the groundwater does not simply cause a lack of water, but it also causes a rise in salinity. The salts dissolved from the limestone had caused high salinity of 85\% of the groundwater by the year 1997 [25].

In addition, groundwater over-pumping now seems likely to have caused an increase in the magnitude of earthquakes. The over-pumping of the ground water would cause pressure release [1], and the absence of water would reduce the fluid absorbance of earthquake shocks [26].

Despite the emergence of water problems during the 1980s there are no rules or laws to protect the groundwater. The Federal Law No 24 of 1999 for the protection and development of the environment has a general role, mainly for protection of water resources rather than for groundwater protection itself. Article 39 states: "The concerned parties shall consult and coordinate with the agency and competent authorities in all matters related to drinking and groundwater including the preservation and development of water sources” [27].

\subsection{Cracks and Rock Mines}

There are about 20 rock mines in the area under the risk 
of earthquakes. At least 3 rock mines were initiated between years 2000 and 2003. They are located directly on the Tertiary fault line at the western side of the mountain front. The increase in the number of mines may have accentuated the earthquakes of March 2002. Rock mines may have a direct affect on earthquakes in two ways. First by pressure release by moving the rocks away, and second the rock explosions may have amplified the earthquakes shocks.

\subsection{Response to the Earthquakes Building Age and Materials}

The buildings which were effected by the earthquakes and spread fear among the people are old and have expired their life time. Furthermore, the materials which were used in the buildings were substandard and only suitable for temporary buildings with a life time not more than 15 years. This means that any ground shock may cause the buildings to collapse easily. This happened in March 2002. In other words, the impact of earthquakes would have been lower if the building did not collapse.

\section{Discussions}

Although the fact that the earthquakes in northern UAE mainly occur as a result of the movement of the Arabian Plate towards Iran, human activity seems to have played a major role in the accentuation of the recent earthquakes. It is highly unlikely that sudden natural changes in the physical setting (e.g. rock nature and fault zones) of the study area would have occurred. It is highly likely these earthquakes were by the impact of human activity including possibly groundwater over-pumping and mine explosions. The affects were accentuated by the building age and bad quality building materials.

Table 1 and Figure 3 show the direct relationships between groundwater over-pumping and the earthquakes. This is in accordance with the literature. For instance [26] suggested that the fluid acts as a shock absorber [11]. This means that the evacuation of water may lead to stronger shocks being felt, as a result of the absence of groundwater to absorb the shock. This can be related to all high magnitude earthquakes in the area over the past 30 years. Figure 3 shows strong relationships between earthquake events and groundwater over-pumping, the results of population growth, agriculture expansion and industrial development. For instance, the strength of the earthquakes in the years 1975, 1977, 1980 ranged between 5 and 5.2 on the Richter scale. The major change in this period was overdrawing of groundwater as a result of population growth and increasing farm numbers (See Figure 3). By 1975 the population had tripled from 180,000 in year 1968 to 560,000 . By the same year farm numbers tripled from 1600 in 1968 to 5000 in year 1975
Table 1. Earthquakes magnitudes in the northern UAE between 1975 and 2002, according to army force in $\mathrm{Al}$ Fujerah. And suggested reasons for earthquakes high magnitude involve; groundwater over-pumping resulted of either population growth or number of farms growth or combination of both (For more details, see Figure 3 and the text).

\begin{tabular}{|c|c|c|}
\hline Year & Magnitude & Suggested reason for the earthquakes \\
\hline 1975 & 5.2 & $\begin{array}{l}\text { Sudden population growth as a result } \\
\text { of initiation of the country in } 1972\end{array}$ \\
\hline 1977 & 5.1 & \\
\hline 1980 & 5 & Population growth and agriculture growth \\
\hline 1986 & 5.4 & $\begin{array}{l}\text { Population growth and agriculture and } \\
\text { number of mine growth }\end{array}$ \\
\hline 1994 & 5.3 & $\begin{array}{l}\text { Population growth and agriculture and } \\
\text { number of mine growth and number } \\
\text { of bottled water factories growth }\end{array}$ \\
\hline 1995 & 4.8 & \\
\hline 1997 & 3.6 & \\
\hline 1998 & 4.6 & \\
\hline 2000 & 4.7 & \\
\hline 2002 & 5.5 & $\begin{array}{l}\text { Over pumping of the groundwater from } \\
\text { Massafi wells to export it to USA } \\
\text { army in Afghanistan }\end{array}$ \\
\hline Main & 4.4 & \\
\hline
\end{tabular}

(Ministry of Agriculture, 1975). The population doubled and farm numbers were tripled again during the period from 1975 to 1980 (see Figure 3). In 1986 the strength of the earthquakes was 5.4 on the Richter scale. Although population growth had slowed down as had the increase in the number of the farms between 1980 and 1986, there was growth of rock mines and bottled water factories. In 1994 the strength of the earthquakes was 5.3 on the Richter scale. During the period between 1986 and 1994 there was growth in all of the previous mentioned factors. Earthquake magnitudes in 1995, 1997 and 1998 were less than 5 on the Richter scale (4.8, 3.6 and 4.6 respectively). This may indicate a similar growth of all previous factors. However, the earthquakes in 2002 were between 5.1 and 5.5 on the Richter scale. In that year there was massive over-pumping from bottled mineral water companies which were exporting water to the US army in Afghanistan. In addition, water consumption per person per day in the UAE is one of the highest worldwide (90 gallons per person) [28]. This sudden consumption of the groundwater may have accentuated earthquake strength and magnitude. This is different from what had occurred elsewhere (Denver and Nasser Lake) where injection of water into the ground caused earthquakes. This means that any change in groundwater volume, whether an increase or decrease, may cause accentuation of the magnitude in the earthquakes. 


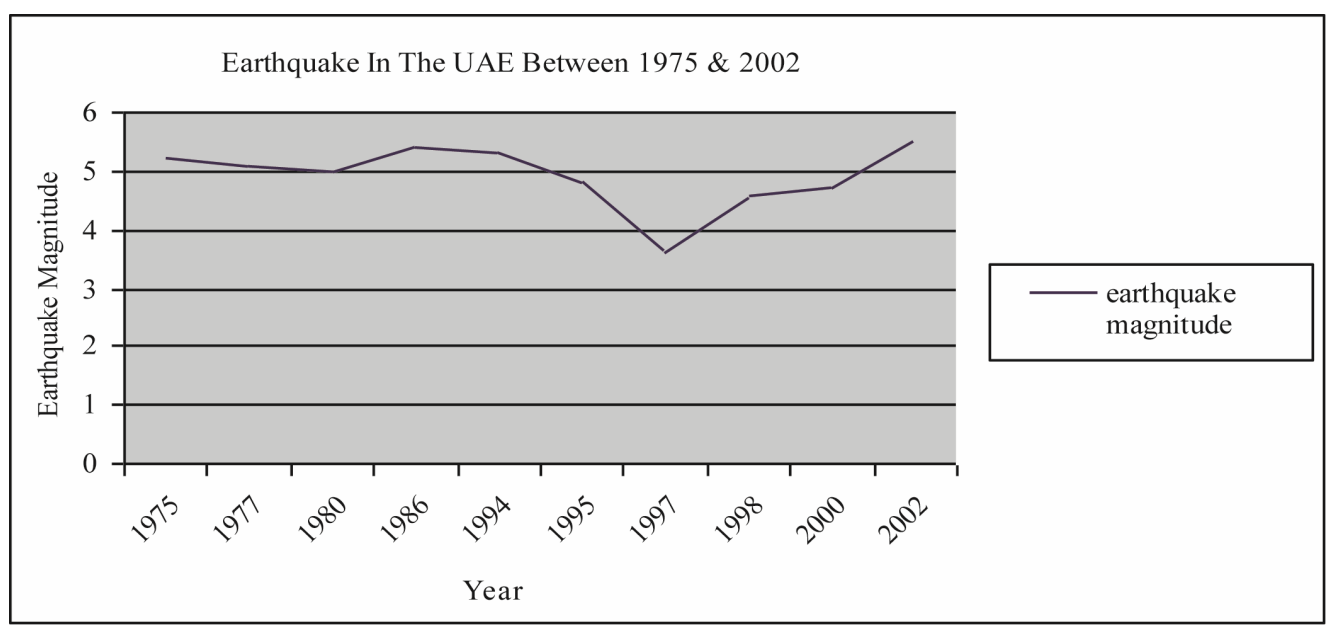

(a)

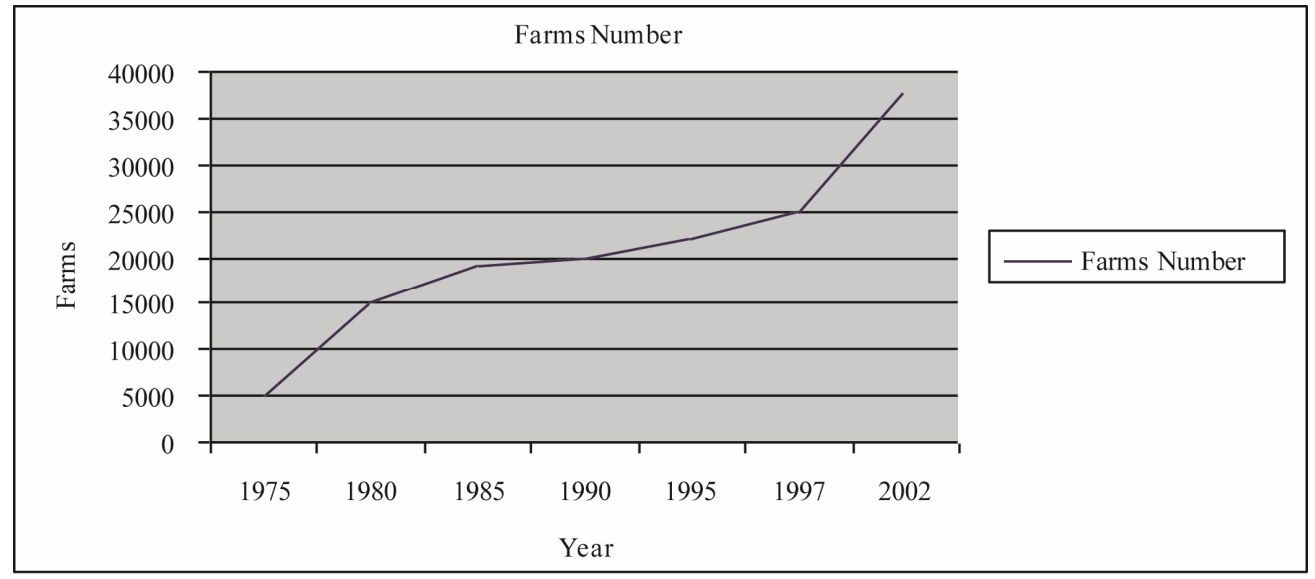

(b)

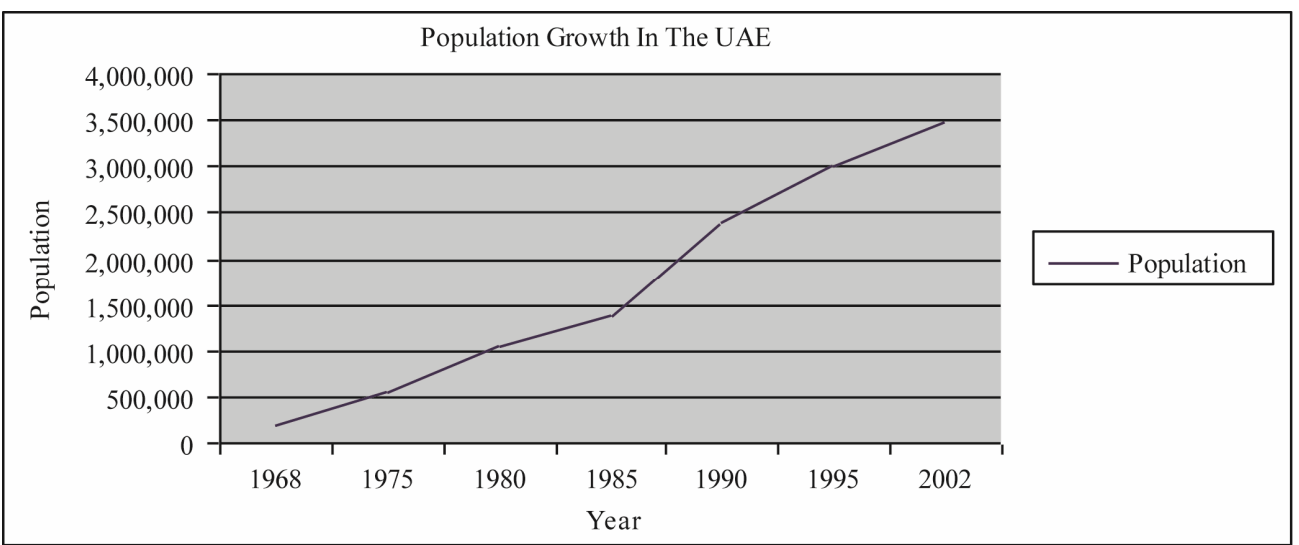

(c)

Figure 3. General view of the relationship between earthquakes and groundwater over pumping in the UAE; (a) earthquakes between 1975 and 2002; (b) Population in the UAE between 1968 and 2002; (c) Number of farms between 1968 and 2002. The groundwater data are from ministry of agriculture annual static publications (for years, 1975, 1980, 1985, 1990, 1995, 2000, 2002).

The rock mining industry in the northern UAE may have a negative impact on bedrock stability, through the use of mining explosions. These induce cracks in the rocks and cause pressure release. However, this impact may be still small and may not have as direct an influence on earthquakes as groundwater over-pumping. But, 
combining both factors together would make the situation worse.

\section{Conclusions}

Although major Tertiary fault lines divide the terrain of the northern UAE, they play only a minor role in the earthquake magnitude of the area. The major earthquakes are generated along the plate boundary in Iran, but it appears that human activity may play a role in earthquake accentuation within the UAE. Groundwater over-pumping especially seems to have a direct relationship with earthquake events during the past three decades. This indicates that any change in groundwater conditions may accentuate earthquake magnitudes. This may act together with the minor impact of rock mining. Building age and poor quality materials accentuate the damage causes by the earthquakes.

In summary, the high magnitude of earthquakes which have occurred in the northern UAE, is not related to major or sudden changes in the earth's crust, but may have been accentuated in response to ground water overpumping together with an increase in mining activity.

\section{Acknowledgements}

I am grateful to Miss Moza Al-Mualla from the Ministry of Communication for providing some data on the earthquakes in the area. I also wish to acknowledge the assistance of Prof. Adrian Harvey for his help in the English corrections. I also would like to thank Athari Al Shuwaihi for her help in drawing the figures for this work.

\section{REFERENCES}

[1] B. A. Bolt, “Earthquakes,” W. H. Freeman and Company, New York, 1993, 331 p.

[2] B. A. Bolt, "Earthquakes,” W. H. Freeman and Company, New York, 1999, 421 p.

[3] S. Stein and M. Wysession, "An Introduction to Seismology. Earthquakes and Earth Structure,” Blackwell Publishing, Cornwall, 2003, 498 p.

[4] A. Nur and J. R. Booker, "Aftershocks by Pore Fluid Flow?” Science, Vol. 175, No. 4024, 1972, pp. 885-887. doi:10.1126/science.175.4024.885

[5] J. R. Rice and J. W. Rudnick, "Earthquake Precursory Effects Due to Pore Fluid Stabilization of a Weakening Fault Zone,” Journal of Geophysical Research, Vol. 84, No. B5, 1979, pp. 2177-2193. doi:10.1029/JB084iB05p02177

[6] W. Chengmin, "Ground-Water Studies for Earthquake Prediction in China. Eathquake Hydrology and Chemistry,” Pure and Applied Geophysics, Vol. 122, No. 2-4, 1985, pp. 215-217. doi:10.1007/BF00874594

[7] J. Byerlee, "Model for Episodic Flow of High-Pressure Water in Fault Zone before Earthquakes,” Geology, Vol.
21, 1993, pp. 303-306.

[8] E. Roeloffs, "Poroelastic Techniques in the Study of Earthquake-Related Hydrologic Phenomena,” Advances in Geophysics, Vol. 37, 1996, pp. 135-195. doi:10.1016/S0065-2687(08)60270-8

[9] G. Peltzer, P. Rosen, F. Rogez and K. Hudnut, "Postseismic Rebound in Fault Step-Overs Caused by Pore Fluid Flow,” Science, Vol. 273, No. 5279, 1996, pp. 1202-1204. doi:10.1126/science.273.5279.1202

[10] W. J. Bosl and A. Nur, "Crustal Fluids and Earthquakes," Geophysical Monograph, Vol. 120, 2000, pp. 267-284. doi:10.1029/GM120p0267

[11] J. Walder and A. Nur, "Porosity Reduction and Crustal Pore Pressure Development," Journal of Geophysical Research, Vol. 89, No. B13, 1984, pp. 11539-11548. doi:10.1029/JB089iB13p11539

[12] G. M. Lees, "The Geology and Tectonics of Oman and Parts of South-Eastern Arabia,” Geological Society London Quarterly Journal, Vol. 84, 1928, pp. 585-670. doi:10.1144/GSL.JGS.1928.084.01-04.24

[13] R. G. S. Hudson, "The Permian and Trias of the Oman Peninsula, Arabia,” Geologica Magazine, Vol. 97, No. 4, 1960, pp. 299-308. doi:10.1017/S0016756800061550

[14] R. G. S. Hudson and M. Chattan, "The Musandam Limestone (Jurassic to Lower Cretaceous) of Oman Arabia," Notes \& Mémoires sur le Moyen-Orient, Vol. 3, 1959, pp. 69-93.

[15] R. G. S. Hudson, A. McGugan and D. M. Morton, "The Structure of Jebel Hagab Area, Trucial Oman,” Geological Society London Quarterly Journal, Vol. 110, 1954, pp. 121-152. doi:10.1144/GSL.JGS.1954.110.01-04.08

[16] F. Alleman and T. Peters, "The Ophiolite-Radiolarite Belt of the North Oman Mountains,” Eclogae Geologicae Helvetiae, Vol. 65, 1972, pp. 657-697.

[17] K. W. Glennie, M. G. A. Boeuf, B. M. Hughes-Clark, M. W. Moody-Stuart, W. F. H. Pilaar and B. M. Reinhardt, "Late Cretaceous Nappes in Oman Mountains and Their Geologic Evolution,” The American Association of Petroleum Geologists Bulletin, Vol. 57, 1973, pp. 5-27.

[18] K. W. Glennie, M. G. A. Boeuff, M. W. Hughes-Clarke, M. Moody-Stuart, W. H. F. Pilaar and B. M. Reinhart, "Geology of the Oman Mountains," Vol. 33, 1974, p. 423.

[19] A. Ricateau, and P. H. Riche, "Geology of the Musandam Peninsula (Sultanate of Oman) and Its Surroundings," Journal of Petroleum Geology, Vol. 3, No. 2, 1980, pp. 139-152. doi:10.1111/j.1747-5457.1980.tb00979.x

[20] M. P. Searle, "Structure of the Musandam Culmination (Sultanate of Oman and United Arab Emirates and the Straits of Hormuz Syntaxes,” Journal of the Geological Society London, Vol. 145, 1988, pp. 831-845.

[21] M. P. Searle, N. P. James, T. J. Calon and J. D. Smewing, "Sedimentlogical and Structural Evolution of the Arabian Continental Margin in Musandam Mountains and Dibba Zone, UAE,” Geological Society of America, Vol. 94, No. 12, 1983, pp. 1381. doi:10.1130/0016-7606(1983)94<1381:SASEOT >2.0.CO 
;2

[22] Al-Khaleej Newspaper, 17 March 2003, p. 10.

[23] National Atlas of United Arab Emirates, United Arab Emirates University Al-Ain, 1993.

[24] Federal Electricity and Water Authority, Internal Reports, 2003.

[25] M. M. M. Al-Mulla, “Application of Geophysical, HydroGeological and GIS Techniques for Investigation of Groundwater Resource in the Al Dhaid Area," UAE Ms.
Thesis, UAE University, 2001.

[26] W. J. Bosl and A. Nur, "Crustal Fluids and Earthquakes," Geophysical Monograph, Vol. 120, 2000, pp. 267-284. doi:10.1029/GM120p0267

[27] Federal Low No. (24) of 1999 for the Protection and Development of the Environment. United Arab Emirates, Federal Environmental Agency, 1999.

[28] Al Bayan Newspaper, 2 August 2000, p. 6. 